\title{
The Greek Cypriot Nationalist Right in the Era of British Colonialism: Emergence, Mobilisation and Transformations of Right-Wing Party Politics
}

Review Number: 2264

Publish date: Thursday, 12 July, 2018

Author: Yiannos Katsourides

ISBN: 9783319555348

Date of Publication: 2017

Price: $£ 89.99$

Pages: 228pp.

Publisher: Springer International Publishing AG

Publisher url: https://www.springer.com/gb/book/9783319555348

Place of Publication: Basel

Reviewer: Andrekos Varnava

After publishing his first monograph in 2014 on communism in Cyprus, Yiannos Katsourides has backed this up with this book on the emergence of the Greek Cypriot nationalist right. While the former looked at communism until the formation of AKEL in 1942, this latest work extends the period of focus until the end of the British colonial period. In both cases the methodology adopted is similar, reflective of Katsourides' discipline, political science, rather than that of history; thus both books are not grounded in the thorough and meticulous analysis of the archives, and are based to a larger extent on secondary sources and published primary sources, supplemented by the sporadic use of the archives. This in no way diminishes the worth of either, but places each in their appropriate methodological context.

Katsourides states that the aims of his book are to analyse the processes and factors that contributed to the emergence, constitution and consolidation of the Greek Cypriot nationalist right during colonialism. This he achieves, and for the most part he presents a good case, even if it does lack an archival grounding. The chronological-thematic structure adopted is appropriate and the period is covered relatively thoroughly within the confines of the research undertaken, which is mainly based on secondary sources with a good use of Cypriot newspapers, Blue Books and some Colonial Office files. One minor irritation is that the referencing system adopted is hard to follow, as primary sources appear in the footnotes and secondary sources in the text.

The broader argument of the book is satisfactory, namely that the Greek Cypriot nationalist right emerged just prior to the start of the Great War from the distinctive social classes that had developed over the previous decades, and grew during the inter-war years. These socio-political classes comprised the educated and semi-educated elites, including the 'old elites' of landowners and traders, including some members of the church, who were more reliant on the British (as they had been on the Ottomans) for their livelihoods and status, and the 'new elites' of white-collar workers such as lawyers, doctors and teachers, including some clergy, as well as a more volatile middle class, including a bourgeoisie as well as a less affluent shopkeeper and artisan class. Katsourides shows how there were social and institutional shortcomings which 
stunted social mobility and distorted party politics. I would agree that the constitution was partly responsible, but I would not blame it as much as Katsourides and I would not place emphasis - certainly not the same negative emphasis - on the consociational element, which was by and large a common approach across the British Empire wherever religious differences existed to protect minorities. I would agree that voting restrictions were a serious impediment to democratisation and contributed to the emergence of a Greek Cypriot nationalist right, in the same way as they also contributed, with the emergence of AKEL in the 1940s, to its brand of nationalist, or pro-enosis, communism. What I think needs to be explored further in this regard is the exclusion of the working and peasant classes from the historical record, and their eventual politicisation, mostly into extreme right- and extreme left-wing camps by the 1940s. This was despite the British insistence that they were not in favour of enosis (which was mostly true), and wanted British rule (which was a stretch because they were indifferent to both). By and large it would seem that the working and peasant classes were won over to the extreme nationalist right and left because there was no British support for moderate political forces, as was the case in Malta, because they feared that all Greek Cypriots were proenosis, as Rappas showed in his discussion of the constitutional movement late in the 1930s. The critical period is therefore the inter-war years, as shown by Rappas, but I think this needs further development in relation to the rise of communism and fascism and its influence on the left and right in Cyprus, especially the pro-enosis movement. Additionally, further work is needed on the Cypriots who attempted to carve a road to enosis by working more closely with the British and how they both failed and yet influenced the extreme left and right which came to dominate.

For a book reliant on secondary literature there is on the one hand omissions and on the other a surprising reliance on old works which are anachronistic or works that lack rigour and peer review. As regards omissions, the most obvious ones are the books by Rebecca Bryant, Alexis Rappas, and David French.(1) Then there are several edited volumes, such as that by Emilios Solomou \& Hubert Faustmann, and myself with Michalis N. Michael, which were not consulted thoroughly.(2) As for articles and book chapters, several authors seem to have been consulted thoroughly, such as George Georghallides and Rolandos Katiaounis, while others, such as Bryant and myself have not been. In my case I am especially thinking about a book chapter I co-authored with Christalla Yakinthou on democratic deficit in Cyprus taking a long historical approach, which makes similar arguments about the colonial origins of democratic deficit in Cyprus. $\underline{(3)}$

As for primary sources, the combination of political science and history approaches make it difficult to assess how effectively these were used, but there is an impressive array. Happily, Katsourides consulted the recently released FCO files (the so called 'migrated files'), although he could have explored these even more. Generally, if this were a work of pure history, I would expect more archival work, but bearing in mind its origins in political science, I am in fact impressed with the use of primary sources.

Nevertheless, there are factual and other errors, misplaced/wrong words, and parochial comments. Various random examples are: the use of the anachronistic phrase 'despotic' Ottoman Empire; the constant references to 'Greek community' or 'Greeks of Cyprus' where nuanced clarification is needed; Cyprus was not 'purchased' by Britain in 1878; the claim that there was an 'enduring myth of enosis' in 1878; mistakenly claiming Amiantos and Skouriotissa to be mining companies - they were places that contained mines; the references to a government report from the 1930s footnoted with a publication from the 1990s; the simplistic idea that the British and the smaller communities ganged up against 'the Greeks'; mistakenly claiming that Haynes-Smith was the high commissioner in the 1930s; comparing patronage to Greece and not the British Empire, which I think is more appropriate; the claim that Britain needed or used Cyprus as a naval base; the belief that the demand for enosis was a matter of 'dignity' (perhaps for the nationalists, but this comes across as parochial when not clarified); the misunderstanding in quoting my work on page 86 the British did not address education because of the uncertainty of their tenure, but because policy-makers in London considered the island to be 'Greek'; the use of the work of Papapolyviou on the role of Greek Cypriots in the Balkan Wars, which ignores the fact that about ten times more Cypriots served in the British armed forces; the insinuation that the Cypriot Orthodox Church was more or less the same under Ottoman and British rule; the generalisation that the Greek Cypriot population universally respected the church; the 
claim that Makarios I was elected archbishop in 1916 and died in exile in 1933 - it was Kyrillos II who was elected in 1916 and he died in Cyprus, not in exile; and, to keep the list short, the errors in the figures for the 1953 elections, since Katsourides claims that the Right won 58.8 per cent and the Left 45.3 per cent, bring the total to over 100 .

Despite this, overall, this is a worthy follow-up to Katsourides' previous book, addressing an important question and raising further research problems.

\section{Notes}

1. Rebecca Bryant, Imagining the Modern (London, 2004); Alexis Rappas, Cyprus in the 1930s (London, 2014); David French, Fighting EOKA (Oxford, 2015).Back to (1)

2. Colonial Cyprus 1878-1960, ed. Emilios Solomou \& Hubert Faustmann (Nicosia, 2010); The Archbishops of Cyprus in the Modern Age, ed. Andrekos Varnava and Michalis N. Michael (Cambridge, 2013).Back to (2)

3. Andrekos Varnava and Christalla Yakinthou, 'Cyprus: political modernity and the structures of democracy in a divided island', in The Oxford Handbook of Local and Regional Democracy in Europe , ed. John Loughlin, Frank Hendriks and Anders Lidstrom (Oxford, 2011), pp. 455-77. Back to (3)

Source URL:https://reviews.history.ac.uk/review/2264

\section{Links}

[1] https://reviews.history.ac.uk/item/272952 